\title{
Effect of condensed corn distillers solubles concentration on lactation performance of Holstein cows
}

\author{
M. E. McCormick, ${ }^{* 1}$ S. Forbes, ${ }^{*}$ V. R. Moreira, ${ }^{*}$ D. C. Blouin, $†$ and K. J. Han $\ddagger$ \\ *Southeast Research Station, Louisiana State University Agricultural Center, Franklinton 70438 \\ †Department of Experimental Statistics, and \\ $\ddagger$ School of Plant and Environmental Science, Louisiana State University, Baton Rouge 70803
}

\section{ABSTRACT}

Forty-eight Holstein cows (32 multiparous and 16 primiparous) in mid to late lactation averaging $219 \pm 71$ days in milk and $30.5 \pm 6.6 \mathrm{~kg} / \mathrm{d}$ of $3.5 \%$ fat-corrected milk were used in a 56-d completely randomized design experiment to evaluate condensed corn distillers solubles (CCDS) inclusion in high-fiber total mixed rations (TMR). Inclusion rates evaluated were 0, 6.6, 13.2, and $19.8 \%$ CCDS as a percentage of dry matter (DM). Distiller solubles substituted for soybean meal, corn grain, and whole cottonseed such that diets were similar in protein $(16.6 \%)$ and fat $(4.50 \%)$. Water was added to 0, 6.6, and $13.2 \%$ CCDS treatments so that final TMR DM concentrations (47.8\%) were similar across diets. The forage portion of the diet was kept constant at $19.6 \%$ annual ryegrass hay and $26.0 \%$ sorghum baleage. Diet in vitro true digestibility tended to increase as CCDS addition increased, but neutral detergent fiber digestibility trended lower in CCDS diets. Percent $\mathrm{P}$ $(0.39,0.55,0.69$, and $0.73 \%)$ and $\mathrm{S}(0.32,0.35,0.39$, and $0.42 \%$ ) in TMR increased as CCDS concentration increased. Milk yield $(23.5,24.7,25.5$, and $24.8 \mathrm{~kg} / \mathrm{d}$ of $3.5 \%$ fat-corrected milk) was similar for control and CCDS diets. Milk fat $(3.88,3.73,3.78$, and $3.68 \%)$, protein $(3.28,3.27,3.31$, and $3.31 \%)$, and lactose (4.61, $4.66,4.69$, and 4.77) percentages were similar across diets. Milk urea nitrogen $(16.60,15.58,15.43$, and 14.75 $\mathrm{mg} / \mathrm{dL}$ ) declined with increasing CCDS addition. Animal activity, body weight, body condition scores, and locomotion scores were not influenced by CCDS. Day 28 poststudy locomotion scores were similar across diets. Ruminal acetate concentrations did not differ among diets, but propionate and butyrate concentrations were elevated in rumen fluid of cows receiving 19.6\% CCDS. Although rumen fluid $\mathrm{pH}$ values were similar $(6.5,6.4$, 6.3, and 6.2), the two highest CCDS diets exhibited depressed acetate:propionate ratios relative to controls.

Received September 9, 2014.

Accepted November 24, 2014.

${ }^{1}$ Corresponding author: memccormick@agctr.lsu.edu
The results from this study indicate that CCDS may be included in high-fiber TMR for lactating dairy cows at up to nearly $20 \%$ of diet DM; however, caution is recommended because high CCDS $\mathrm{P}$ concentrations may create $\mathrm{Ca}: \mathrm{P}$ imbalances and excess $\mathrm{P}$ may be introduced into the environment.

Key words: condensed corn distillers solubles, lactating dairy cattle, total mixed ration

\section{INTRODUCTION}

Recent estimates are that more than $40 \%$ of the corn grown for grain in the United States was used by the ethanol biofuel industry in 2013 (USDA, 2014). A consequence of this expansion is increased availability of ethanol by-products. Each pound of corn used in ethanol production generates about one-third pound of dried distillers grains, the most popular ethanol byproduct fed to livestock. Other by-product feeds such as wet corn distillers solubles, corn germ and several new by-products are becoming increasingly available to the cattle industry (Schingoethe et al., 2009).

The by-product condensed corn distillers solubles (CCDS), also known as corn syrup, is a condensed form of corn stillage remaining after ethanol production. This product is normally dried and added back to dried distillers grains (dried distillers grains plus solubles), but some ethanol plants offer CCDS for sale to livestock producers within a reasonable trucking distance.

As with many agricultural by-products, nutrient composition of CCDS can be quite variable. Several reports indicate that CCDS may contain as little as $17 \%$ and as much as $27 \% \mathrm{CP}$, with fat levels ranging from less than 5\% (Gilbery et al., 2006) to more than $20 \%$ (Da Cruz et al., 2005). Although data are limited, the rumen undegradable protein content of CCDS has been estimated to range from as little as 15\% (Gilbery et al., 2006) to as high as 30\% of total protein (Schingoethe et al., 2009). The by-product is also known to be quite high in $\mathrm{P}, \mathrm{K}$, and $\mathrm{S}$, and concentrations of these minerals often vary considerably between ethanol 
plants due to different management practices employed in ethanol manufacture. More recent data indicate that ethanol plants are condensing the thin stillage to DM ranging from 27 to $35 \%$ (Gilbery et al., 2006; Warner et al., 2011). However, remaining moisture in these CCDS products continues to limit the distance this product can economically be transported.

In some of the earlier research, Hatch et al. (1972) demonstrated that including $2.5 \%$ distillers solubles as a replacement for urea in liquid protein supplements improved weight gain and feed conversion for finishing beef steers. Subsequent finishing cattle studies with CCDS also noted improved feed conversion (Rust et al., 1990; Ham et al., 1994), whereas others observed improved weight gains in finishing cattle receiving up to $20 \%$ CCDS (Sharp and Berkelo, 1996). In supporting research, Nebraska workers (Larson et al., 1993) reported that, as a whole, wet distillers products contained an average of $169 \%$ of the energy present in rolled corn for yearling cattle and $128 \%$ when fed to calves.

Relatively high fat content in CCDS has created concern with respect to its potential negative impact on rumen fermentation and digestion. Corn oil has been shown to reduce DM and fiber digestion in both sheep and cattle (Palmquist and Jenkins, 1980; Jenkins and Fotouhi, 1990). Most dietary supplementation research with CCDS that contained more than $8 \%$ fat elicited a depression in rumen acetate, a decrease in acetate:propionate ratio, and an increase in butyrate suggestive of reduced ruminal fiber digestion. However, in high-fiber diets containing as much as 15\% CCDS, no adverse effects on rumen or total tract digestibility were recorded (Gilbery et al., 2006). Moreover, in a recent review on feeding distillers by-products to dairy cattle (Schingoethe et al., 2009), it was noted that cattle receiving TMR diets containing CCDS seldom experienced significantly impaired fiber digestion or milk fat depression when fed $50 \%$ or more forage in TMR.

Distillers solubles have been evaluated as a substitute for corn and soybean meal in lactating dairy cattle diets (DaCruz et al., 2005; Sasikala-Appukuttan et al., 2008). In the study by DaCruz et al. (2005), milk yield increased with CCDS addition to corn silage-alfalfa hay-based diets, but no differences were noted between diets containing 5 or $10 \%$ CCDS. In a follow up lactation study, CCDS was tested at 0,10 , and $20 \%$ of diet DM. Milk yield tended to be higher with increasing CCDS level, but no differences were noted for DMI or feed efficiency (FE). The authors suggested that higher performance was likely due to higher energy content in diets containing CCDS and noted that CCDS was effective in replacing up to $20 \%$ corn and soybean meal in corn silage-alfalfa hay-based TMR.
Since the above-mentioned research was conducted, producers have seen large increases in corn, soybean, and other feed ingredient prices. Thus, interest in feeding high levels of CCDS has grown, particularly for those in close proximity to ethanol plants that offer this product at a reasonable price. Little research exists studying dietary CCDS supplementation in lactating dairy cows offered high-fiber diets. Nor have previous studies attempted to evaluate CCDS fat relative to other common seed-grain fat sources such as whole cottonseed. Therefore, this project was initiated to study the effect of feeding $0,6.6,13.2$, and $19.8 \%$ CCDS to mid lactation Holstein cows receiving sorghum baleage and ryegrass hay-based TMR. Distillers soluble nutrients were substituted for corn, soybean meal, and whole cottonseed such that diets were similar in protein and fat content.

\section{MATERIALS AND METHODS}

Forty-eight Holstein cows (32 multiparous and 16 primiparous) in mid to late lactation averaging 219 \pm 71 DIM and $30.5 \pm 6.6 \mathrm{~kg} / \mathrm{d}$ of FCM were used in a 56-d completely randomized design experiment to evaluate CCDS inclusion in high-fiber diets. This study was conducted at the Louisiana State University Agricultural Center's Southeast Research Station located near Franklinton $\left(30^{\circ} 47^{\prime} 04^{\prime \prime} \mathrm{N}\right.$ and $\left.90^{\circ} 12^{\prime} 19^{\prime \prime} \mathrm{W}\right)$. All animal procedures were approved by the Louisiana State University Agricultural Center's Animal Care Committee (protocol A2011-19). Cows were stratified according to DIM, parity, and milk production and randomly assigned to 4 CCDS treatments representing $0,6.6,13.2$, or $19.8 \%$ of diet $\mathrm{DM}$ or $0,15,30$, or $45 \%$ of concentrate DM. Cows were fed experimental TMR in a 64-cow free stall barn equipped with Calan gates (American Calan Inc., Northwood, NH) for measuring individual TMR consumption. Cows were allowed a minimum of $14 \mathrm{~d}$ for adaptation to Calan gates. Following adaptation to the feeding barn, cows were offered a common corn silage-based TMR for $10 \mathrm{~d}$ during which animal performance data were collected and used for covariance analysis.

Experimental diets were designed to be similar in DM, protein, and fat content (NRC 2001). Ingredients utilized were BMR 108 forage sorghum (Croplan Genetics, Land O'Lakes, Inc., Minneapolis, MN) baleage, Prine annual ryegrass (Reagan and Massey Seeds Inc., Ponchatoula, LA), hay, ground corn, soybean meal, whole cottonseed, custom dairy minerals, and CCDS (Table 1). Water was added to TMR as needed to maintain TMR DM at approximately $50 \%$. Whole cottonseed concentration was lowered with increasing CCDS in order to maintain dietary fat concentration at 
Table 1. Ingredient composition of diets containing increasing concentrations of condensed corn distillers solubles (CCDS)

\begin{tabular}{|c|c|c|c|c|}
\hline \multirow{2}{*}{$\begin{array}{l}\text { Ingredient, } \\
\% \text { of diet DM }\end{array}$} & \multicolumn{4}{|c|}{ CCDS concentration, $\%$ of DM } \\
\hline & 0 & 6.6 & 13.2 & 19.8 \\
\hline Ryegrass hay & 19.0 & 19.0 & 19.0 & 19.0 \\
\hline Sorghum baleage & 26.6 & 26.6 & 26.6 & 26.6 \\
\hline Corn, ground & 27.2 & 24.4 & 21.9 & 19.2 \\
\hline Soybean meal, $48 \%$ & 14.7 & 13.2 & 11.8 & 10.4 \\
\hline Cottonseed, whole & 10.1 & 8.0 & 5.5 & 3.2 \\
\hline CCDS & 0.0 & 6.6 & 13.2 & 19.8 \\
\hline Dairy mineral $^{1}$ & 1.9 & 1.7 & 1.5 & 1.3 \\
\hline Calcium carbonate & 0.5 & 0.5 & 0.5 & 0.5 \\
\hline
\end{tabular}

${ }^{1}$ Custom dairy mineral containing $23 \% \mathrm{Ca}, 4 \% \mathrm{P}, 6 \% \mathrm{Mg}, 3 \% \mathrm{~S}, 6 \% \mathrm{~K}, 2,700 \mathrm{mg} / \mathrm{kg}$ of Zn (inorganic), 1,000 $\mathrm{mg} / \mathrm{kg}$ of Zn methionine, $1,200 \mathrm{mg} / \mathrm{kg}$ of $\mathrm{Mn}, 650 \mathrm{mg} / \mathrm{kg}$ of Cu, $50 \mathrm{mg} / \mathrm{kg}$ of I, $15 \mathrm{mg} / \mathrm{kg}$ of Co, $18 \mathrm{mg} / \mathrm{kg}$ of Se, $660 \mathrm{kIU}$ of vitamin $\mathrm{A} / \mathrm{kg}, 66 \mathrm{kIU}$ of vitamin $\mathrm{D} / \mathrm{kg}, 33 \mathrm{kIU}$ of vitamin $\mathrm{E} / \mathrm{kg}$, and $0.20 \%$ Rumensin- 80 (Elanco Animal Health, Greenfield, IN).

about $4.5 \%$ of DM. Otherwise, CCDS substituted for corn and soybean meal in experimental diets. Forage accounted for approximately $45 \%$ of diet DM, and concentrate, including CCDS, accounted for $55 \%$ of diet DM. Fresh bales of sorghum baleage and ryegrass hay were ground daily with a flail-type hay grinder (model 2554 HayBuster, McConnell Machinery Co., Lawrence, $\mathrm{KS}$ ), and a basal forage mix was then prepared in a vertical mixer wagon (Jaylor model 3650, Orton, Ontario, Canada). Concentrate components were added to a Calan Data Ranger (American Calan Inc.) to complete experimental TMR (Table 1). The CCDS was mechanically agitated for $0.25 \mathrm{~h}$ prior to being added to experimental diets. All CCDS was purchased weekly in 1,000-kg plastic carboys from a local vendor. The CCDS was generated at the Bunge-Ergon ethanol plant in Vicksburg, Mississippi.

Diets were fed twice daily (0800 and $1500 \mathrm{~h})$ in amounts to allow for ad libitum consumption. Orts were weighed immediately prior to morning feeding and recorded daily for each animal. Ort and TMR samples were collected on Monday, Wednesday, and Friday of each week and composited to form weekly samples, which were dried at $55^{\circ} \mathrm{C}$ for $48 \mathrm{~h}$, ground to $1 \mathrm{~mm}$, and stored in plastic airtight vials for subsequent lab analyses. Baleage, hay, and concentrate samples, including CCDS, were obtained weekly and processed as described above. Ground samples were analyzed for DM and CP (micro Kjeldahl) according to AOAC (1990) procedures. Sample ADF and NDF concentrations were determined using detergent fiber methods of Van Soest et al. (1971). Sodium sulfite and amylase were added to NDF solutions before fiber analyses were conducted. In vitro digestibility of silage samples was determined by the 2-stage rumen fermentation-pepsin technique as described by Goering and Van Soest (1970). Experimental TMR were tested for NDF digestibility by measuring NDF concentrations before and after a 48-h in vitro fermentation (NRC, 2001). Baleage VFA were determined by gas chromatography (Bateman et al., 2002), and lactic acid concentrations were determined via the enzymatic conversion of L-lactate to pyruvate using the YSI 2700 Select Biochemistry Analyzer (YSI Inc., Yellow Springs, OH). Weekly CCDS and TMR samples were analyzed for ether extract using the Goldfish method (AOAC, 1990). Aflatoxin $\mathrm{B}_{1}$ concentrations in CCDS were determined using HPLC according to AOAC (1990; method 994.08). Mineral analyses on feed, forage, and TMR samples were determined using inductively coupled plasma optical emission spectroscopy (EPA method 200.7). Crude fat concentrations were determined from an ether extraction using the Soxtec System (Foss Inc., Eden Prairie, MN; AOAC, 1990; method 945.16).

Cows were milked twice daily at 0400 and $1500 \mathrm{~h}$. At each milking, milk yield and conductivity for each cow were measured in AfiFlo milk meters (Afimilk, Kibbutz Afikim, Israel). Animal activity (steps/h) was also downloaded at each milking using AfiTag pedometers (Afimilk). Composites of a.m. and p.m. milk samples were collected weekly, preserved with 2-bromo, 2 nitropropane-1, 3-diol, and analyzed for fat, protein, MUN, and lactose via infrared spectroscopy (Mid-South Dairy Herd Improvement Association, St. Louis, MO). Milk SCC was determined via flow cytometry. Body weights, BCS $(1=$ extremely thin and $5=$ extremely obese; Edmonson et al., 1989), and locomotion scores (1 = normal and $5=$ extremely lame; Sprecher et al., 1997) were recorded on 2 consecutive days at study initiation and conclusion and on d 14, 28, and 42. Locomotion scores were also recorded on d 84 (4 wk after study conclusion) to assess potential long-term effects of CCDS level on cattle lameness. Condition and locomotion scores were assigned by 3 independent observers. 
On the morning of $\mathrm{d} 56,10 \mathrm{~mL}$ of rumen fluid was collected approximately $4 \mathrm{~h}$ postfeeding from each animal via rumenocentesis (Nordlund et al., 1994). Rumen fluid $\mathrm{pH}$ was measured immediately with an Orion model 230A portable $\mathrm{pH}$ meter (Orion Research Inc., Boston, MA), and the sample was then placed on ice until transported to the Southeast Research Station Forage Quality Laboratory. Five milliliters of rumen fluid was sterilized with $1.0 \mathrm{~mL}$ of $25 \%$ meta-phosphoric acid, and samples were centrifuged at 7,000 $\times g$ for 10 min in a refrigerated centrifuge $\left(4^{\circ} \mathrm{C}\right)$, filtered through a $2.0-\mu \mathrm{m}$ filter, and stored at $-20^{\circ} \mathrm{C}$. Rumen fluid VFA were determined by gas chromatography (Bateman et al., 2002).

Lactation performance data were statistically analyzed using the MIXED procedure of SAS (SAS Institute, 2001). All daily intake and milk production data were reduced to cow-week means before statistical analysis. The model for the lactation performance data included CCDS level, week, and CCDS $\times$ week as fixed effects, cow nested within CCDS level as random effects, and cows by week as residual error effects. Performance data collected during the standardization period were used as covariables for the dependent variables. Rumen fluid $\mathrm{pH}$ and VFA were evaluated using GLM procedures with a model that included CCDS level tested against residual error. Least square means were separated using Tukey-Kramer adjustment and results are accompanied by the highest standard error. Statistical differences between means were declared at $P<0.05$, and tendencies were reported at $P>0.05$ and $<0.10$.

\section{RESULTS AND DISCUSSION}

\section{Nutrient Content of Feed Ingredients and Diets}

Experimental diets contained approximately $45 \%$ forage as sorghum baleage and ryegrass hay and 55\% concentrates derived from corn, soybean meal, cottonseed, CCDS, and minerals (Table 1). Condensed corn distillers solubles substituted for approximately $30 \%$ of the corn, soybean meal, and minerals and $68 \%$ of the whole cottonseed at the highest concentration evaluated $(19.6 \%$ of DM).

Chemical composition of CCDS was relatively constant throughout the study as indicated by low standard deviation values for CCDS chemical constituents (Table 2). Average distillers solubles DM, CP, and ether extract concentrations were 33.1, 18.8, and 9.8\%, respectively. Dry matter and CP content of CCDS were similar to the average ranges 27 to $31 \%$ for DM and 18.1 to $19.5 \%$ for CP previously reported (Gilbery et al., 2006; Sasikala-Appukuttan et al., 2008). In con- trast, CCDS in the present experiment contained about $10 \%$ crude fat, which was similar to that reported by Warner et al. (2011), but less than half the average ether extract concentrations reported in other studies (Da Cruz et al., 2005; Sasikala-Appukuttan et al., 2008). Differences in crude fat concentration may be related to variations in CCDS manufacture between ethanol plants. Large variations in nutrient composition of distillers by-products have been previously reported (Spiehs et al., 2002).

Mineral concentrations for CCDS, forages, and experimental diets are presented in Table 2. The CCDS contained unusually low levels of $\mathrm{Ca}$ and high concentrations of $\mathrm{P}$. Therefore, experimental diets $\mathrm{Ca}: \mathrm{P}$ ratio declined with increasing CCDS concentration and fell slightly below 1:1 at the highest CCDS supplementation level. Our custom dairy mineral was low in P $(4 \%)$, which was necessary to prevent the $\mathrm{Ca}: \mathrm{P}$ ratio from falling below 1:1, the lower limit for lactating dairy cattle (NRC, 2001). Moreover, P concentrations in diets containing CCDS were from 40 to $100 \%$ higher than recommended for these lactating Holsteins, which may have contributed excess $\mathrm{P}$ into the environment. Sulfur concentration in CCDS approached 1\% of DM, but with the exception of the highest CCDS diet, concentrations in experimental diets were below $0.40 \%$, the recommended maximum $\mathrm{S}$ concentration in dairy cattle diets (NRC, 2001). The CCDS contained an average of $17.2 \mu \mathrm{g} / \mathrm{kg}$ aflatoxins, which is below the maximum 20 $\mu \mathrm{g} / \mathrm{kg}$ allowed by the Food and Drug Administration for use in dairy cattle diets. However, as indicated by the relatively high standard deviations, 1 or 2 CCDS samples did exceed the $20 \mu \mathrm{g} / \mathrm{kg}$ threshold.

Use of water additions to balance differences between CCDS DM and that of substituted concentrates enabled maintenance of relatively constant DM concentrations in experimental diets (Table 2). Previous research indicated DM reductions of up to 10 percentage units with CCDS supplementation (Da Cruz et al., 2005; Sasikala-Appukuttan et al., 2008) compared to less than 3 percentage unit differences in our diets. Diet CP concentrations were $16.5 \%$, which were slightly lower than the desired $17 \% \mathrm{CP}$, this being attributed to lower than anticipated CP in ryegrass hay. Dietary crude fat concentrations were similar across diets, though fat from whole cottonseed decreased as CCDS supplementation level increased. As expected, fiber fractions declined with increasing CCDS and in vitro true digestibility increased slightly. In spite of the trend toward higher in vitro true digestibility with CCDS supplementation, diets containing CCDS were somewhat lower in NDF digestibility than the control diet containing 0\% CCDS. One of the major concerns with feeding large amounts of CCDS to cattle has been the potential effect of its 
Table 2. Mean nutrient value and standard deviation of ryegrass hay (RH), sorghum baleage (SB), condensed corn distillers solubles (CCDS), concentrate mix (CM), and TMR for $0,6.6,13.2$, and $19.8 \%$ CCDS concentrations

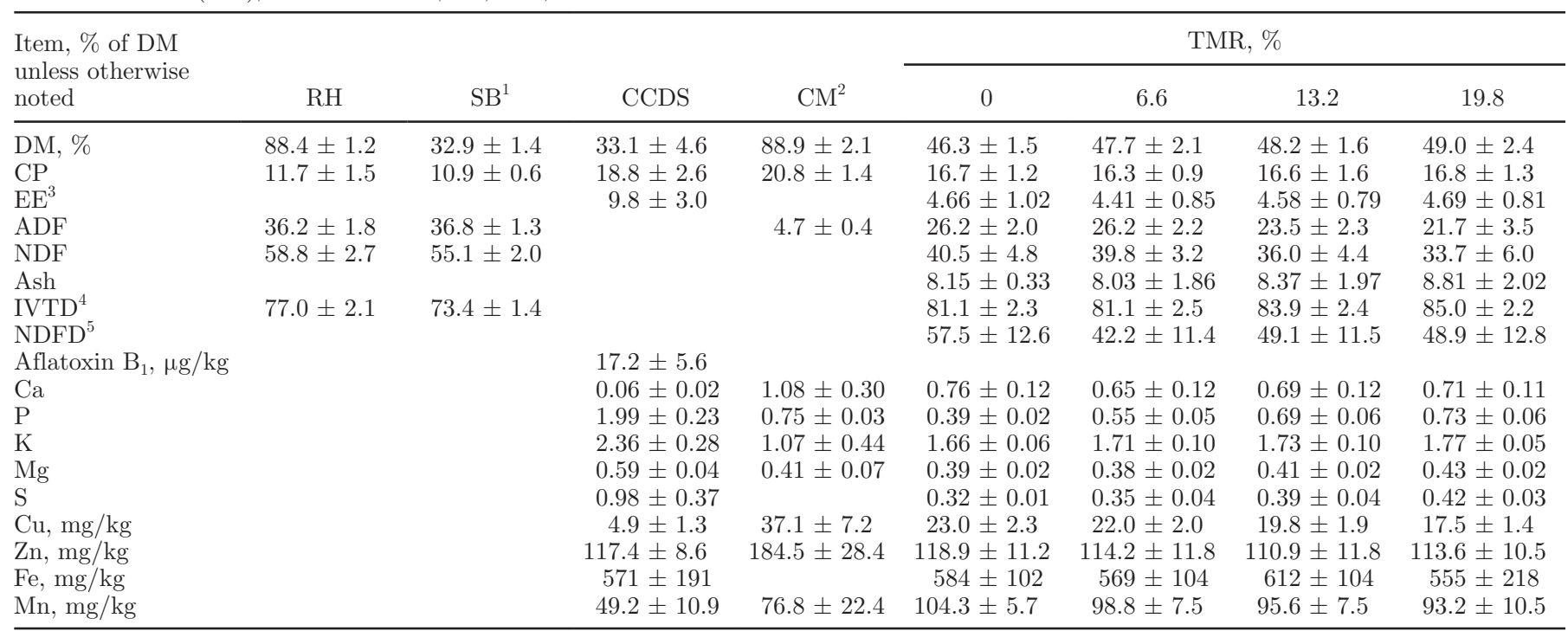

${ }^{1} \mathrm{SB}$ fermentation characteristics: $\mathrm{pH}=4.25 \pm 0.06$; lactic acid $=2.7 \pm 0.28 \%$; acetic acid $=1.42 \pm 0.09 \%$; propionic acid $=0.09 \pm 0.01 \%$; butyric acid $=0.03 \pm 0.03$; and isobutyric acid $=0.18 \pm 0.10 \%$.

${ }^{2} \mathrm{CM}=$ corn-soybean meal-mineral mix used in all TMR.

${ }^{3} \mathrm{EE}=$ ether extract.

${ }^{4}$ IVTD $=$ in vitro true digestibility.

${ }^{5} \mathrm{NDFD}=$ neutral detergent fiber digestibility.

soluble fat on dietary fiber digestion (Schingoethe et al., 2009). In a beef steer feeding study, supplementation with CCDS improved switchgrass fiber and DM digestibility (Gilbery et al., 2006). However, CCDS used in that study contained only $4.2 \%$ fat and improvements in digestibility were attributed to increased microbial protein synthesis. Though no specific studies have been conducted to assess CCDS fat effects on fiber digestion in dairy diets, Schingoethe et al. (2009) in a review on the use of distillers products in dairy cattle diets, concluded that for diets containing $50 \%$ or more forage and adequate effective fiber, CCDS-induced depression in fiber digestibility was not likely to be a problem. In our study, CCDS fat substituted for whole cottonseed fat. The oil in CCDS likely is more soluble and more readily biohydrogenated in rumen liquor than cottonseed fat increasing its potential to inhibit ruminal fiber digestibility.

\section{Diet Consumption and Lactation Performance}

Dry matter consumption was similar across diets (Table 3), but lower than previously reported for lactating dairy cows supplemented with CCDS (Da Cruz et al., 2005; Bharathan et al., 2008; Sasikala-Appukuttan et al., 2008). Lower DMI in the present study was likely related to low diet DM, high dietary NDF concentrations, later lactation cows, or a combination of these factors. Fiber intake was not affected by CCDS concentration though numerically lower concentrations in the highest supplementation level may have been a reflection of the lower NDF concentrations prevalent with increasing CCDS additions (Table 2).

Milk yield and FE were similar across all levels of CCDS supplementation (Table 3). Using an energy value for CCDS of $2.09 \mathrm{Mcal}$ of $\mathrm{NE}_{\mathrm{L}} / \mathrm{kg}$ (Schingoethe et al, 2009), diets were expected to generate an average of $32.2 \mathrm{~kg}$ of $3.5 \% \mathrm{FCM} / \mathrm{d}$ (NRC, 2001), which was considerably higher than the $24.7 \mathrm{~kg} / \mathrm{d}$ FCM average observed in this study, this primarily being related to high dietary NDF and lower than expected DMI. Others have noted dairy cow lactation performance similar to controls when CCDS composed $10 \%$ of diet DM (Bharathan et al., 2008). In contrast, other researchers have noted improvements in milk production with CCDS supplementation (Da Cruz et al., 2005; Sasikala-Appukuttan et al., 2008). However, in these reports diets were not balanced for additional fat from CCDS, which led to higher dietary energy concentrations as CCDS supplementation increased. Our diets were balanced for fat concentration; therefore energy intake was similar across dietary treatments, and given similar DMI, no increases in ECM yield were expected. Based on milk yield and diet nutrient composition, CCDS used in the present study contained $2.07 \mathrm{Mcal}$ of $\mathrm{NE}_{\mathrm{L}} / \mathrm{kg}$, which was similar to the $2.09 \mathrm{Mcal} / \mathrm{kg}$ of $\mathrm{NE}_{\mathrm{L}}$ 
Table 3. Lactation performance, BW, BCS, and locomotion scores of Holstein cows fed 0, 6.6, 13.2, or 19.8\% condensed corn distillers solubles (CCDS)

\begin{tabular}{|c|c|c|c|c|c|c|c|c|}
\hline \multirow[b]{2}{*}{ Item } & \multicolumn{4}{|c|}{ CCDS concentration, $\%$ of DM } & \multirow[b]{2}{*}{ SEM } & \multicolumn{3}{|c|}{$P$-value } \\
\hline & 0.0 & 6.6 & 13.2 & 19.8 & & $\mathrm{CCDS}$ & Week & $\begin{array}{r}\text { CCDS } \\
\times \text { week }\end{array}$ \\
\hline DMI, $\mathrm{kg} / \mathrm{d}$ & 19.5 & 19.6 & 20.6 & 20.9 & 0.66 & 0.37 & $<0.01$ & $<0.01$ \\
\hline NDF intake, $\mathrm{kg} / \mathrm{d}$ & 7.7 & 7.9 & 7.4 & 7.0 & 0.27 & 0.22 & $<0.01$ & $<0.01$ \\
\hline Milk yield, kg/d & 23.8 & 23.3 & 24.6 & 24.0 & 0.84 & 0.54 & $<0.01$ & 0.70 \\
\hline $3.5 \% \mathrm{FCM}, \mathrm{kg} / \mathrm{d}$ & 23.8 & 24.7 & 25.5 & 24.8 & 1.03 & 0.72 & $<0.01$ & 0.89 \\
\hline $\mathrm{FE}^{1}{ }^{1} \mathrm{~kg}$ of $\mathrm{FCM} / \mathrm{kg}$ of DMI & 1.22 & 1.26 & 1.24 & 1.19 & 0.10 & 0.58 & $<0.01$ & $<0.01$ \\
\hline Fat, $\%$ & 3.88 & 3.73 & 3.78 & 3.68 & 0.10 & 0.55 & $<0.01$ & 0.46 \\
\hline Fat, kg/d & 0.92 & 0.87 & 0.93 & 0.88 & 0.03 & 0.45 & $<0.01$ & 0.44 \\
\hline Protein, $\%$ & 3.28 & 3.27 & 3.31 & 3.31 & 0.05 & 0.89 & $<0.01$ & 0.50 \\
\hline Protein, kg/d & 0.78 & 0.76 & 0.81 & 0.79 & 0.02 & 0.45 & $<0.01$ & 0.42 \\
\hline Lactose, $\%$ & 4.61 & 4.66 & 4.69 & 4.77 & 0.06 & 0.28 & $<0.01$ & 0.18 \\
\hline Lactose, kg/d & 1.10 & 1.09 & 1.15 & 1.14 & 0.03 & 0.23 & $<0.01$ & 0.22 \\
\hline $\mathrm{SCC}, \times 10^{3} / \mathrm{mL}$ & 180.1 & 291.2 & 320.2 & 283.7 & 63.1 & 0.43 & 0.85 & 0.73 \\
\hline Milk conductivity, $\mathrm{mS}$ & 11.12 & 11.34 & 10.96 & 11.07 & 0.11 & 0.10 & 0.07 & 0.24 \\
\hline MUN, mg/dL & $16.60^{\mathrm{a}}$ & $15.58^{\mathrm{ab}}$ & $15.43^{\mathrm{ab}}$ & $14.75^{\mathrm{b}}$ & 0.41 & 0.02 & $<0.01$ & $<0.01$ \\
\hline Activity, steps/h & 103.7 & 119.2 & 108.2 & 102.3 & 6.6 & 0.26 & $<0.01$ & 0.35 \\
\hline Initial BW, kg & 655.1 & 652.2 & 680.3 & 660.4 & 9.8 & 0.74 & & \\
\hline Final BW, kg & 672.0 & 676.0 & 704.4 & 681.5 & 9.9 & 0.65 & & \\
\hline BW change, kg & 17.0 & 23.8 & 24.1 & 21.1 & 2.2 & 0.58 & & \\
\hline Initial $\mathrm{BCS}^{2}$ & 3.00 & 3.00 & 2.98 & 3.08 & 0.12 & 0.91 & & \\
\hline Final BCS & 2.14 & 2.59 & 2.27 & 2.76 & 0.35 & 0.46 & & \\
\hline BCS change & -0.87 & -0.42 & -0.72 & -0.33 & 0.36 & 0.56 & & \\
\hline Initial locomotion score ${ }^{3}$ & 1.53 & 1.54 & 1.61 & 1.61 & 0.16 & 0.96 & & \\
\hline Final locomotion score & 1.58 & 1.58 & 1.47 & 1.69 & 0.26 & 0.92 & & \\
\hline Locomotion score change & 0.06 & 0.04 & -0.14 & 0.08 & 0.28 & 0.91 & & \\
\hline Locomotion score, ${ }^{4} \mathrm{~d} 84$ & 1.54 & 1.56 & 1.47 & 1.44 & 0.22 & 0.94 & & \\
\hline
\end{tabular}

${ }^{\mathrm{a}, \mathrm{b}}$ Least square means in rows with different superscripts differ significantly $(P<0.05)$.

${ }^{1} \mathrm{FE}=$ feed efficiency

${ }^{2}$ Body condition score: $1=$ extremely thin and $5=$ extremely obese.

${ }^{3}$ Locomotion score: $1=$ normal and $5=$ extremely lame (incumbent).

${ }^{4}$ Locomotion scores taken 28 d after study conclusion.

reported by Schingoethe et al. (2009) for milk cows but lower than reported by Larson et al. (1993) for finishing beef cattle. Higher energy content in beef cattle diets was attributed to lower dietary starch or improvements in energy availability due to the effects of yeast and other micronutrients found in CCDS. Improvements in FE were not seen in the present evaluation nor were they observed in previous CCDS supplementation work (Sharp and Berkelo, 1996; Da Cruz et al., 2005). Lack of improvements in FE may have been related to slight depressions in fiber digestibility, which may have negated increased energy availability through CCDS fat contributions.

Percentage and yield of milk fat, protein, and lactose did not differ with diet $(P>0.10)$. Milk fat percentage ranged from 3.68 to $3.88 \%$ (Table 3 ), which are typical values for late lactation cows consuming high-fiber diets. In contrast, Bharathan et al. (2008) recorded a decline in milk fat percentage from 3.62 to $3.23 \%$ and Da Cruz et al. (2005) saw milk fat percentage drop from 3.54 to $3.33 \%$ for milk cows receiving $10 \%$ CCDS. In both of these studies, cows were earlier in stage of lactation, diets contained less NDF, and CCDS fat content was more than double that described in the present report. One or more of these factors may explain why we did not observe milk fat depression with increasing CCDS supplementation.

Milk protein and lactose percentage and yield varied little with experimental diets, a finding consistent with that of Sasikala-Appukuttan et al. (2008) who observed similar protein and lactose concentrations in milk cows fed 0 , 10, or 20\% CCDS. Milk urea nitrogen concentration decreased $(P<0.02)$ with CCDS addition falling from $16.6 \mathrm{mg} / \mathrm{dL}$ for controls to $14.7 \mathrm{mg} / \mathrm{dL}$ at the $19.8 \%$ CCDS supplementation level. Although RUP data are lacking, the MUN decrease with CCDS addition suggests that RUP of CCDS is considerably higher than that found in soybean meal and corn. Dried distiller grains, brewers grains, and other grain by-products are usually moderate to high in RUP (Schingoethe et al., 2009), and depressed MUN observed in the current study and others (Da Cruz et al., 2005; Sasikala-Appukuttan et al., 2008) suggests the same may be true for CCDS. 
Table 4. Ruminal VFA and $\mathrm{pH}$ for Holstein cows fed diets containing 0, 6.6, 13.2, or 19.8\% condensed corn distillers solubles (CCDS)

\begin{tabular}{|c|c|c|c|c|c|c|}
\hline \multirow[b]{2}{*}{ Item } & \multicolumn{4}{|c|}{ CCDS concentration, $\%$ of DM } & \multirow[b]{2}{*}{ SE } & \multirow[b]{2}{*}{$P$-value } \\
\hline & 0 & 6.6 & 13.2 & 19.8 & & \\
\hline \multicolumn{7}{|l|}{$\mathrm{VFA}, \mu \mathrm{mol} / \mathrm{mL}$} \\
\hline Acetate $(\mathrm{A})$ & 57.4 & 63.8 & 44.5 & 63.1 & 4.62 & 0.31 \\
\hline Propionate $(\mathrm{P})$ & 15.5 & 18.3 & 13.8 & 23.7 & 1.72 & 0.10 \\
\hline Isobutyrate & 1.1 & 1.3 & 0.9 & 1.1 & 0.14 & 0.73 \\
\hline Butyrate & 9.8 & 11.4 & 9.1 & 15.7 & 1.25 & 0.10 \\
\hline Isovalerate & 1.7 & 1.6 & 1.1 & 1.9 & 0.21 & 0.51 \\
\hline Valerate & 1.4 & 1.6 & 1.3 & 1.9 & 0.18 & 0.50 \\
\hline Total & 86.9 & 98.0 & 70.7 & 107.4 & 7.58 & 0.24 \\
\hline $\mathrm{A}: \mathrm{P}$ ratio & $3.76^{\mathrm{a}}$ & $3.50^{\mathrm{ab}}$ & $3.23^{\mathrm{b}}$ & $2.77^{\mathrm{c}}$ & 0.17 & $<0.01$ \\
\hline $\mathrm{pH}$ & 6.5 & 6.4 & 6.3 & 6.2 & 0.05 & 0.44 \\
\hline
\end{tabular}

${ }^{\mathrm{a}-\mathrm{c}}$ Means in a row with different superscripts differ significantly $(P<0.05)$.

Animal activity (steps/h), BW, BCS, and locomotion scores were not influenced by CCDS supplementation levels $(P>0.10$; Table 3$)$. Cow BW and BCS reacted in opposite directions from study initiation to conclusion with weight increasing and BCS decreasing over time. This contradiction may be explained by reductions in fat depots, the primary factor used in BCS determination, while overall body mass increased. Losses in fat reserves may have been related to low DMI observed for all experimental diets. Locomotion scores are highly correlated to laminitis and overall hoof quality (Norlund et al., 2004), and risk factors for laminitis may include suboptimal fiber concentrations and impaired rumen NDF digestion. Low locomotion scores $(1=$ normal gait to $5=$ extremely lame) in the present study imply that rumen function was normal and effective fiber was more than adequate even at the highest (19.8\%) CCDS treatment. The fact that no changes in locomotion score were noted $28 \mathrm{~d}$ after study conclusion further supports our contention that CCDS may be fed at quite high levels in dairy cattle diets provided adequate effective fiber is available.

Ruminal VFA and $\mathrm{pH}$ for Holstein cows fed diets containing $0,6.6,13.2$, or $19.8 \%$ CCDS are presented in Table 4. Rumen acetate, isobutyrate, isovalerate, and valerate concentrations were similar for all diets. However, a trend was noted for higher $(P<0.10)$ propionate and butyrate in rumen fluid of cows fed the highest $(19.8 \%)$ CCDS level. The trend toward higher propionate at the $19.8 \%$ CCDS feeding rate resulted in a lower $(P<0.01)$ ruminal acetate:propionate ratio than observed for other diets. Previous researchers have also observed increased butyrate (Sharp and Berkelo, 1996; Bharathan et al., 2008) decreased acetate (Bharathan et al., 2008; Sasikala-Appukuttan et al., 2008) and lower acetate:propionate ratios (Ham et al., 1994) for CCDS-supplemented cows.
Rumen fluid $\mathrm{pH}$ means ranged from 6.2 to 6.4 in cows fed CCDS, but no level of supplementation effect was detected. However, one cow fed the $19.8 \%$ CCDS diet did have a rumen $\mathrm{pH}$ of 5.57 , which is slightly lower than the $5.6 \mathrm{pH}$ threshold associated with SARA (Nordlund et al., 2004).

\section{CONCLUSIONS}

Data from this study indicate that CCDS is readily consumed by mid to late lactation Holstein cows and lactation performance is similar to that achieved with a corn-soybean meal-whole cottonseed control diet when formulated for similar protein and fat content. Feeding up to $19.8 \%$ of diet DMI ( $45 \%$ of concentrates) as CCDS in high NDF diets did not alter milk yield nor did it adversely affect rumen metabolism or animal health. However, caution should be exercised when feeding excessive amounts of CCDS because high $\mathrm{P}$ concentrations may lead to Ca:P imbalances and high $\mathrm{S}$ concentrations could induce polioencephalomalacialike symptoms in cows. Distillers by-products such as CCDS may be an economical alternative to traditional concentrates for dairy producers in close proximity to ethanol plants.

\section{ACKNOWLEDGMENTS}

The authors are grateful to Bill Barber, Doug McKean, and Paul Thompson for feed preparation and cow management (Southeast Research Station, Franklinton, LA). The authors also thank Laura Zeringue (Southeast Research Station Forage Quality Laboratory, Franklinton, LA) for assistance with laboratory analyses. In addition, we gratefully acknowledge partial funding for the CCDS through Drude Minerals and Commodities Inc. (Husser, LA). 


\section{REFERENCES}

AOAC. 1990. Official Methods of Analysis. 15th ed. AOAC., Arlington, VA.

Bateman, H. G., C. C. Williams, and Y. H. Chung. 2002. Effects of supplemental zinc in high quality diets on rumen fermentation and degradation of urea in vitro and in vivo. Prof. Anim. Sci. 18:363-367.

Bharathan, M., D. J. Schingoethe, A. R. Hippen, K. F. Kalscheur, M. L. Gibson, and K. Karges. 2008. Conjugated linoleic acid increases in milk from cows fed condensed corn distillers solubles and fish oil. J. Dairy Sci. 91:2796-2807.

Da Cruz, C. R., M. J. Brouk, and D. J. Schingoethe. 2005. Lactation response of cows fed condensed corn distillers solubles. J. Dairy Sci. 88:4000-4006.

Edmonson, A. J., I. J. Lean, L. D. Weaver, T. Farver, and G. Webster. 1989. A body condition scoring chart of Holstein dairy cows. J. Dairy Sci. 72:68-78.

Gilbery, T. C., G. P. Lardy, S. A. Soto-Navarro, M. L. Bauer, and J. S. Caton. 2006. Effects of corn condensed distillers solubles supplementation on ruminal fermentation, digestion, and in situ disappearance in steers consuming low quality hay. J. Anim. Sci. $84: 1468-1480$

Goering, H. K., and P. J. Van Soest. 1970. Forage fiber analyses (apparatus, reagents, procedures and some applications). USDA-ARS, US Gov. Print. Office, Washington, DC

Ham, G. A., R. A. Stock, T. J. Klopenstein, E. M. Larson, D. H. Shain, and R. P. Huffman. 1994. Wet corn distillers by-products compared with dried corn distillers grains with solubles as a source of protein and energy for ruminants. J. Anim. Sci. 72:3246-3257.

Hatch, C. F., T. W. Perry, M. T. Mohler, and W. M. Beeson. 1972. Effect of corn distillers solubles and brewers dried grains with yeast in urea-containing rations on steer performance. J. Anim. Sci. 34:326-331.

Jenkins, T. C., and N. Fotouhi. 1990. Effects of lecithin and corn oil on site of digestion, ruminal fermentation and microbial protein synthesis in sheep. J. Anim. Sci. 68:460-466.

Larson, E. M., R. A. Stock, T. J. Klopenstein, M. H. Sindt, and R. P. Huffman. 1993. Feeding value of wet distillers by-products for finishing ruminants. J. Anim. Sci. 71:2228-2236.

Nordlund, K. V., N. B. Cook, and G. R. Oetzel. 2004. Investigation strategies for laminitis in problem herds. J. Dairy Sci. 87(E. Suppl.):E27-E35.
Nordlund, K. V., and E. F. Garrett. 1994. Rumenocentesis: A technique for the diagnosis of sub-acute rumen acidosis in dairy herds. Bovine Pract. 28:109-122.

NRC. 2001. Nutrient Requirements of Dairy Cattle. 7th rev. ed. Natl Acad. Sci., Washington, DC.

Palmquist, D. L., and T. C. Jenkins. 1980. Fat in lactation rations . J Dairy Sci. 63:1-14. (review).

Rust, S. R., J. R. Newbold, and K. W. Metz. 1990. Evaluation of condensed corn distiller's as an energy source for finishing cattle. J. Anim. Sci. 68:186-192.

SAS Institute. 2001. User's Guide: Statistics, Version 8.1. 1st ed. 2001. SAS Inst. Inc., Cary, NC.

Sasikala-Appukuttan, A. K., D. J. Schingoethe, A. R. Hippen, and K. F. Kalscheur. 2008. The feeding value of corn distillers solubles for lactating dairy cows. J. Dairy Sci. 91:279-287.

Schingoethe, D. J., K. F. Kalscheur, A. R. Hippen, and A. D. Garcia 2009. Invited review: The use of distillers products in dairy cattle diets. J. Dairy Sci. 92:5802-5813.

Sharp, G. A., and C. P. Berkelo. 1996. Effect of increasing levels of condensed corn distillers solubles on performance of finishing steers. SDSU Cattle Feeding Report 96-3, pp. 7-9.

Spiehs, M. J., M. H. Whitney, and G. C. Shurson. 2002. Nutrient database for distiller's dried grains with solubles produced from new ethanol plants in Minnesota and South Dakota. J. Anim. Sci. 80:2639-2645

Sprecher, D. J., D. E. Hoestetler, and J. B. Kaneene. 1997. A lameness scoring system that uses posture and gait to predict dairy cattle reproductive performance. Theriogenology 47:1179-1187.

USDA. 2014. Corn crop production survey in the U.S. Background. USDA Economic Research Service. Accessed Apr. 14, 2014. http:// www.ers.usda.gov/topics/crops/corn/background.aspx.

Van Soest, P. J., J. B. Robertson, and B. A. Lewis. 1991. Methods for dietary fiber, neutral detergent fiber and non-starch polysaccharides in relation to animal nutrition. J. Dairy Sci. 74:3583-3597.

Warner, J. M., L. M. Kovarick, G. E. Erikson, and R. J. Rasby. 2011 Limit feeding non-lactating, non-pregnant beef cows with bunkered wet distillers grains plus solubles or distillers solubles. Prof. Anim. Sci. 27:456-460. 